\title{
Cost-benefit analysis for invasive species control: the case of greater Canada goose Branta canadensis in Flanders (northern Belgium)
}

\author{
Nikolaas Reyns ${ }^{1}$, Jim Casaer $^{2}$, Lieven De Smet ${ }^{2}$, Koen Devos ${ }^{2}$, Frank Huysentruyt ${ }^{2}$, Peter A Robertson ${ }^{3}$, \\ Tom Verbeke ${ }^{4}$, Tim Adriaens ${ }^{\text {Corresp. } 2}$ \\ 1 University of Ghent, Ghent, Belgium \\ 2 Research Institute for Nature and Forest (INBO), Brussels, Belgium \\ ${ }^{3}$ Centre for Wildlife Management, Newcastle University, Newcastle, United Kingdom \\ 4 Research Centre for Economics and Corporate Sustainability, University of Leuven, Brussels, Belgium \\ Corresponding Author: Tim Adriaens \\ Email address: tim.adriaens@inbo.be
}

Background. Sound decisions on control actions for established invasive alien species (IAS) require information on ecological as well as socio-economic impact of the species and of its management. Costbenefit analysis provides part of this information, yet has received relatively little attention in the scientific literature on IAS.

Methods. We apply a bio-economic model in a cost-benefit analysis framework to greater Canada goose Branta canadensis, an IAS with documented social, economic and ecological impacts in Flanders (northern Belgium). We compared a business as usual (BAU) scenario which involved non-coordinated hunting and egg destruction with an enhanced scenario based on a continuation of these activities but supplemented with coordinated capture of moulting birds. To assess population growth under the BAU scenario we fitted a logistic growth model to the observed pre-moult capture population. Projected damage costs included water eutrophication and damage to cultivated grasslands and were calculated for all scenarios. Management costs of the moult captures were based on a representative average of the actual cost of planning and executing moult captures.

Results. Comparing the scenario's with different capture rates, different costs for eutrophication and various discount rates, showed avoided damage costs were in the range of 21,15 M€ to 45,82 M€ under the moult capture scenario. The lowest value for the avoided costs applied to the scenario where we lowered the capture rate by $10 \%$. The highest value occurred in the scenario where we lowered the real discount rate from $4 \%$ to $2.5 \%$.

Discussion. The reduction in damage costs always outweighed the additional management costs of moult captures. Therefore, additional coordinated moult captures could be applied to limit the negative economic impact of greater Canada goose at a regional scale. We further discuss the strengths and weaknesses of our approach and its potential application to other IAS. 
1 Cost-benefit analysis for invasive species control: the case of greater Canada goose Branta 2 canadensis in Flanders (northern Belgium)

3

4 Nikolaas Reyns ${ }^{1}$, Jim Casaer ${ }^{2}$, Lieven De Smet $^{2}$, Koen Devos ${ }^{2}$, Frank Huysentruyt ${ }^{2}$, Peter A.

5 Robertson $^{3}$, Tom Verbeke ${ }^{4}$, Tim Adriaens ${ }^{2 *}$

6

$7{ }^{1}$ University of Ghent, Belgium

$8 \quad{ }^{2}$ Research Institute for Nature and Forest (INBO), Havenlaan 88 bus 73, 1000 Brussels, Belgium

$9{ }^{3}$ Centre for Wildlife Management, Newcastle University, Newcastle, NE1 7RU, UK

$10{ }^{4}$ Research Centre for Economics and Corporate Sustainability, University of Leuven,

11 Warmoesberg 26, 1000 Brussels, Belgium

12

$13 *$ Corresponding author:

14 Tim Adriaens

15 INBO, Havenlaan 88 bus 73, 1000 Brussels, Belgium

16 tim.adriaens@inbo.be 


\section{Abstract}

18

19 Background. Sound decisions on control actions for established invasive alien species (IAS)

20 require information on ecological as well as socio-economic impact of the species and of its 21 management. Cost-benefit analysis provides part of this information, yet has received relatively 22 little attention in the scientific literature on IAS.

23 Methods. We apply a bio-economic model in a cost-benefit analysis framework to greater 24 Canada goose Branta canadensis, an IAS with documented social, economic and ecological 25 impacts in Flanders (northern Belgium). We compared a business as usual (BAU) scenario which 26 involved non-coordinated hunting and egg destruction with an enhanced scenario based on a continuation of these activities but supplemented with coordinated capture of moulting birds. To assess population growth under the BAU scenario we fitted a logistic growth model to the observed pre-moult capture population. Projected damage costs included water eutrophication and damage to cultivated grasslands and were calculated for all scenarios. Management costs of the moult captures were based on a representative average of the actual cost of planning and executing moult captures.

Results. Comparing the scenario's with different capture rates, different costs for eutrophication and various discount rates, showed avoided damage costs were in the range of 21,15 M€ to 45,82 M€ under the moult capture scenario. The lowest value for the avoided costs applied to the scenario where we lowered the capture rate by $10 \%$. The highest value occurred in the scenario where we lowered the real discount rate from $4 \%$ to $2.5 \%$.

Discussion. The reduction in damage costs always outweighed the additional management costs of moult captures. Therefore, additional coordinated moult captures could be applied to limit the negative economic impact of greater Canada goose at a regional scale. We further discuss the strengths and weaknesses of our approach and its potential application to other IAS. 


\section{Introduction}

Invasive alien species (IAS) can severely impact on society causing ecological, economic and human health impacts (e.g. Olson 2006; Pejchar and Mooney 2009; Vila et al. 2010; Schindler et al. 2015; Roy et al. 2016). Invasive species are sometimes intentionally introduced to exploit economic benefits associated with them, or have unintentionally crossed geographical barriers to establish elsewhere (Perrings et al. 2002, 2005). In Europe, the number of established IAS is estimated between 1200 to 1800 species (DAISIE 2009). Annual damage and control costs associated with a set of economically relevant IAS were conservatively estimated at $€ 12$ billion for Europe and $£ 1.7$ billion for Great Britain (Kettunen et al. 2008; Scalera 2010; Williams et al. 2010). Moreover, IAS are also a leading cause of biodiversity loss (Scalera et al. 2012; Bellard, Cassey \& Blackburn 2016). As a result, in line with recommendation of the global Convention on Biological Diversity (CBD, Aichi Target 9; https://www.cbd.int/sp/targets/), policy initiatives are now in place in Europe targeting high profile IAS through trade restrictions, border controls, targeted surveillance as well as early warning, rapid response or management obligations (Genovesi et al. 2014; Tollington et al. 2015).

Cost-benefit analysis (CBA) is recognised as an important decision support framework for the management of IAS in Europe. Under new European legislation, species identified as posing a high risk will be listed, and Member States will be required to take appropriate action if listed species are found on their territories. This requires a number of processes to identify species, their associated risks and appropriate management options. Species posing high risks are identified based on risk assessments, for which a number of methods have been developed in recent years (McGeoch et al. 2016). These have to meet quality standards (Roy et al. 2014, Roy et al. in press) and should consider potential damage costs as well as economic benefits of a species. First, when adopting or updating the list of IAS of Union concern (see art. 4 of Regulation $(\mathrm{Eu})$ no 1143/2014 of the European Parliament and of The Council of 22 October 2014 on the prevention and management of the introduction and spread of invasive alien species), the European Commission and Member States need to consider the cost of inaction as well as the cost-effectiveness and socio-economic aspects of listing. Second, derogations from the rapid eradication obligation of regulated species are possible based on either the 
73 unavailability of methods, on expected environmental non-target effects of the management 74 measures taken or on a CBA demonstrating with reasonable certainty that the costs will, in the 75 long term, be exceptionally high and disproportionate to the benefits of eradication (European 76 Union 2014). Third, for established IAS of EU concern, Member States are required to put in 77 place effective management measures. Such measures shall be specific to the Member State, be 78 proportionate to the environmental impact and be based on an analysis of the costs and benefits. Cost benefit analysis including ecological, social and economic aspects is a prominent requirement of the European IAS regulation. However, it has only rarely been applied in a European context and there are currently no clear standards or guidelines for its application on IAS (Tollington et al. 2015).

83

84 Given the need for more efficient allocation of scarce conservation resources (Bottrill et al. 2008), understanding the costs and benefits of IAS management informs decision making (Bourdôt et al. 2015; Daigneault and Brown 2013; Panzacchi et al. 2007). When preventive action or early warning mechanisms fail to prevent invasion, eradication is usually considered the preferred option as this avoids future damage costs (Wittenberg and Cock 2001). There are many examples of successful eradications on islands and the mainland (Robertson et al. 2015b), yet even with limited invasion extent, the required investment can be considerable (e.g. Adriaens et al. 2015). To assess eradication probabilities, data models based on case studies can be used to underpin decision making on managing IAS (Drolet et al. 2014; Drolet et al. 2015). Although these models offer interesting tools to guide decisions on IAS management, the lack of published data still prevents their widespread use. If eradication is not feasible, long term control programs can be considered to mitigate IAS impact. The decision to engage in such programs has to consider various aspects to evaluate the feasibility. More recently, invasion scientists and practitioners have focused on developing robust scoring protocols to assess the feasibility of management (Booy et al. 2017). These protocols are mostly based on local expert knowledge and consider the species distribution and abundance, the probability of reinvasion, the effectiveness of management options, the cost of management, the non-target impacts of management, the prevailing legislation and a supposed understanding of public attitudes towards the envisaged eradication or management measures. Based on this information, experts then assess the different management options. Such expert elicitation can provide an efficient, transparent tool for 
104 decision making (Burgman et al. 2011; Vanderhoeven et al. 2017). Although management costs

105 are broadly evaluated, the cost of inaction or the cost-benefit ratio of the management strategy

106 are not explicitly considered. Hence, there is a need for decision support frameworks that

107 integrate ecological and socio-economic impacts of IAS with information on the effectiveness

108 and costs of potential management options. CBA offers a framework to combine data on

109 management and damage costs.

110

111 Ex ante cost-benefit analysis reveals the management options that yield the highest value for 112 society (Pearce, Atkinson \& Mourato 2006; De Peuter et al. 2007). The management scenarios 113 with the lowest total costs compared with a reference scenario are preferred. For IAS, these costs 114 are typically composed of management costs and damage costs caused by the presence of a 115 species. Benefits accrue over time as increasing damage costs are avoided through management 116 (Wainger et al. 2010). The economically preferred management scenario maximizes avoided 117 costs (Bourdôt et al. 2015). Accounting for the time value of money, costs and benefits are 118 typically discounted by calculating present values (PV). For management of IAS, the scenario 119 returning the highest net PV (calculated as the total discounted loss prevented through 120 management minus the total discounted implementation cost of management) is preferred. 121 Applying CBA to IAS involves estimating management and damage costs under different 122 population growth scenarios. Alternative management scenarios are then compared with a 123 business as usual scenario (BAU) which often refers to a scenario where populations are not 124 under coordinated management (De Wit, Crookes \& Van Wilgen 2001). Cost-benefit analysis 125 following an established methodology recognizes the real cost of management choices and 126 reveals hidden damage cost and economic benefits (Pearce, Atkinson \& Mourato 2006). 127 Performing a CBA however is often data-intensive and examples of comprehensive CBA for 128 IAS are scarce in Europe, but have been produced e.g. for coypu Myocaster coypus (Panzacchi et 129 al. 2007), common ragweed Ambrosia artemisiifolia (Schou \& Jensen 2017) and giant hogweed 130 Heracleum mantegazzianum (Rajmis, Thiele \& Marggraf 2016).

131

132 In this study we carried out a CBA for the management of greater Canada goose Branta 133 canadensis L. $(B c)$ in Flanders (north Belgium) by additionally performing moult captures on top 134 of hunting and fertility reduction (Figure 1) using the avoided cost method (Pearce et al. 2006). 
135 Canada geese have the greatest ecological and economic impact of 26 established alien bird 136 species in the EU (Kumschick and Nentwig 2010). Worldwide, non-native Anseriformes (ducks, 137 geese and swans) mostly have impact through hybridization and herbivory (Rehfisch, Allan \& 138 Austin 2010; Evans, Kumschick \& Blackburn 2016). Impacts of Canada geese include 139 eutrophication of water bodies, damage to agriculture, animal and human health impacts, damage 140 to recreational areas and an increased risk of birdstrikes (Maragakis 2009; van Ham, Genovesi \& 141 Scalera 2013). The species has already realised most of its potential niche in Europe (DAISIE 142 2009) including Flanders. Geese can be actively managed through fertility reduction or through 143 culling which involves shooting during the open season for $B c$ and/or capturing flocks of geese 144 during the moult in which they are flightless (Allan, Kirby \& Feare 1995). Due to the availability 145 of data on regional population size, economic data on management and damage in the study area 146 and data on the effectiveness of different management strategies for geese in general (Klok et al. 147 2010; Schekkerman et al. 2000; van der Jeugd et al. 2006), Bc represents a suitable model 148 species for study in a CBA framework. The aim of this paper is to compare a management 149 strategy based on additional coordinated moult captures (hereafter called the enhanced scenario) 150 with a BAU-scenario in which the current active management strategies applying uncoordinated 151 hunting activities and fertility reduction by destroying eggs are continued (Van Daele et al. 152 2012). Non-lethal strategies to mitigate geese impact locally such as discouraging and 153 redistributing geese to alternate foraging sites, scaring, chemical anti-feedants or various forms 154 of habitat management (e.g. Conover 1985; Melman et al. 2011) are not considered in this 155 exercise. Although these methods can mitigate damage locally they do not represent population 156 management and are mostly poorly effective in reducing damage as they just shift goose 157 problems to other areas (Melman et al. 2011; Tombre, Eythórsson \& Madsen 2013; Simonsen et 158 al. 2016). We present a methodology to calculate damage costs associated with eutrophication 159 and damage to cultivated grasslands by $B c$. We then estimate the management costs under the 160 enhanced scenario, given that both hunting and fertility control which are largely undertaken by 161 non-paid volunteers (hunters and environmental NGO's), are continued. We project the 162 population size over time and calculate the damage costs under both scenarios. Finally, we carry 163 out a sensitivity analysis for population parameters and calculate the difference in PV for a range 164 of possible capture and discount rates. We discuss the strengths and weaknesses of our approach 165 and provide recommendations for the application of this CBA approach to other IAS. 


\section{Material and methods}

168

169 We drafted a bio-economic model in a CBA framework (Figure 2) from the perspective of 170 society in order to minimize the total net social costs associated with $B c$ management in 171 Flanders. We collected information on the biology of the species, its impact and spread, potential 172 management techniques and specific data on the costs of damage. Cost benefit analysis should 173 include all costs and benefits to all affected parties to reflect the true total impact (Pierce et al. 174 2006). In a conceptual analysis phase, we identified at least six types of impact by $B c$ : 175 eutrophication of water bodies, damage to agricultural crops, birdstrikes, damage to public health 176 and amenities, damage to biodiversity and to recreational areas such as golf courses. Here, we 177 only considered the impact of $B c$ through eutrophication and damage to cultivated grasslands as 178 these forms of damage could be directly or indirectly valued in monetary terms and represent the 179 main economic impacts of $B c$. Second, we defined the BAU scenario as the current management practice with comprises uncoordinated shooting and fertility reduction and the enhanced scenario which supplements the BAU scenario with moult capture. We then collected data on the costs of control of the $B c$ population from the principal stakeholder in goose management in the project region. We derived a realistic capture rate based on management and $B c$ population data over recent years. Then, the population was modeled using a logistic growth curve based on 19922009 census data. Subsequently, the $B c$ population was projected to the year 2050 under the two scenarios. Thereafter, the data was combined in a bio-economic model. The time horizon for our

187 CBA is the period 2016-2050. For each scenario we calculated the sum of the present value of management and damage costs. Finally, we conducted a sensitivity analysis on several parameters to test the robustness of our results. First, we varied population parameters $r$ or $K$ of our logistic growth model. Second, we reduced the sales price of hay by $90 \%$ to test whether BAU would become preferable in a scenario with almost no agricultural damage. Third, we varied the capture rate as this parameter directly influences the total management cost. Finally, we also varied the discount rate. 
197 Belgium is a federal country with three administrative regions (Flanders, Wallonia and the

198 Brussels Capital Region) each with their own regional government. Flanders $\left(13,522 \mathrm{~km}^{2}\right)$ is

199 highly urbanized with a landscape consisting of a fragmented and complex mosaic of different

200 forms of land use, primarily agricultural areas (45\%), built-up land (26\%), areas protected under

201 different nature conservation legislations (8\%) and other infrastructure (Poelmans \& Van

202 Rompaey, 2009; Adriaens et al. 2015). In Flanders, several populations of geese have impact on

203 biodiversity and society, including invasive non-native $B c$, native greylag goose Anser anser,

204 feral domestic goose $A$. anser f. domestica, mixed populations of wild and domesticated barnacle

205 goose Branta leucopsis, as well as a number of non-native species like Egyptian goose

206 Alopochen aegyptiacus, bar-headed goose A. indicus and upland goose Chloephaga picta

207 (Vermeersch, Anselin \& Devos 2006). Of these, Bc (11,000 birds), greylag goose (19,000) and

208 Egyptian goose $(3,000)$ are the most abundant species. As count coverage is not complete, these

209 numbers are probably an underestimation of real population numbers present (Devos and

210 Onkelinx 2013). Data on compensation payments in the period 2009-2011 show $B c$ is the most

211 important goose species causing agricultural damage in Flanders in terms of compensation

212 payments to farmers as well as in diversity of crop damage (Van Gils et al. 2009; Van Daele et

213 al. 2012). Canada geese started breeding in the wild in 1973 but have increased since the nineties

214 to about 1,800 breeding pairs in 2000-2002 (Vermeersch et al. 2004). Based on winter census

215 data, the post-breeding population stabilized with an average winter maximum of $11,359 \mathrm{Bc}$ in

216 the period 2010-2015 (Devos and Onkelinx 2013; Devos and T'Jollyn 2016). Impacts of Bc in

217 Flanders include crop damage, eutrophication of ponds and fens, overgrazing, fouling and

218 trampling of vegetations such as reed beds and meadows, soil and water pollution, pathogen

219 transmission and hybridization with native species. Several case studies in Flanders show the

220 presence of $B c$ hampers costly nature restoration projects because of nutrient enrichment through

221 their faeces (van Ham, Genovesi \& Scalera 2013). Based on ringing data, $B c$ can undertake long-

222 distance dispersal within northwest Europe (Voslamber 2011), but the population in Flanders is

223 considered relatively sedentary with birds primarily moving locally for foraging, breeding and

224 moulting, and their home ranges seldom exceed a 50km radius (Cooleman et al. 2005). To

225 reduce their impact, $B c$ are managed in Flanders in an adaptive management approach, using an

226 integrated strategy which involves hunting ( $B c$ is a game species), fertility reduction (egg

227 pricking) and moult capturing which has been upscaled and intensified in recent years. $B c$ are 
228 highly susceptible to moult captures with considerable numbers being caught yearly (on average $2292,000 B c$ per year in the period 2009-2012). $B c$ represent $87 \%$ of the geese caught in such 230 captures (Van Daele et al. 2012). Summer census of the population has shown a significant 231 decrease in $B c$ numbers since 2010 (Huysentruyt et al. 2013; Adriaens et al. 2014). Because 232 wildlife management in Belgium is a responsibility of the regions, $B C$ show limited dispersal, 233 data consistency and data quality is good for Flanders and this is where most management is 234 currently undertaken, the geographic scope of this CBA is the Flemish region only.

\section{Calculation of damage costs}

237

Greater Canada geese are known to exert severe pressure on small water bodies such as ponds, 239 reducing water quality through eutrophication (Allan, Kirby \& Feare 1995; Gosser, Conover \& Mesmer 1997; Kumschick and Nentwig 2010; Smith, Craven \& Curtis 2000). This involves the deposition of high nutrient loads, notably nitrogen $(\mathrm{N})$ and phosphorous $(\mathrm{P})$ (Smith, Tilman \& Nekola 1999). The total nutrient input of $B c$ in the environment was calculated based on Canada geese producing about $500 \mathrm{~g}$ of droppings per day with a moisture content of $80 \%$ and nutrient load concentrations for $\mathrm{N}$ and $\mathrm{P}$ of $24.2 \mathrm{mg} / \mathrm{g}$ and $3.6 \mathrm{mg} / \mathrm{g}$ of dry matter respectively (Ayers et al. 2010; Van Daele et al. 2012). Damage costs for $\mathrm{N}$ and $\mathrm{P}$ were valued in the range of $€ 5$ $€ 74 / \mathrm{kg}$ and $€ 80$ - $€ 800 / \mathrm{kg}$ (2010 prices) respectively based on the Flemish environmental cost model for water sanitation (De Nocker, Broekx \& Liekens 2011; Liekens et al. 2013). As such, we use the cost of water sanitation as a proxy to calculate damage through eutrophication. We calculated total damage costs for eutrophication, multiplying the estimated number of geese per year by an estimated damage cost per goose. Damage costs were calculated under two scenarios, assuming the lowest and the highest unit cost values for $\mathrm{N}$ and $\mathrm{P}$ respectively. Since most water sanitation techniques reduce both $\mathrm{N}$ and $\mathrm{P}$ simultaneously, we did not consider the maximum value for both nutrients simultaneously as this would overestimate the true damage cost (Liekens et al. 2013). Nitrogen concentration in geese droppings is much higher than the phosphorous concentration. In the "high" variant of the two scenarios, we therefore used the highest unit cost value for $\mathrm{N}$ and the lowest for $\mathrm{P}$ removal respectively. 
258 Canada geese damage crops by foraging and trampling on agricultural fields (van der Jeugd et al. 259 2006). In the Netherlands, $58 \%-80 \%$ of compensation payments to farmers were made for 260 damage to grasslands by foraging geese (Lemaire and Wiersma 2011). Geese in Flanders spend 261 about $90 \%$ of their time on grasslands (Huysentruyt and Casaer 2010; Van Gils et al. 2009). 262 Also, winter wheat is a crop often affected by $B c$ (Van Gils et al. 2009). Data on agricultural 263 damage costs in relation to $B c$ numbers were lacking for Flanders. We therefore relied on data 264 from the Netherlands (Data S1). We used seasonal data on compensation payments and geese 265 numbers for greylag goose (Lemaire and Wiersma 2011). This species is abundant in the 266 Netherlands and has similar feeding habits. However, we applied a correction factor of 1.26 to 267 account for the higher daily energy intake of $B c$ compared to $A$. anser (Lemaire and Wiersma 268 2011). We used greylag geese numbers in January as a proxy for the year round geese population 269 because counts of geese were most complete for that month (pers. comm. H. Schekkerman). We 270 further summed the total damaged area over the different seasons. We drafted a regression model 271 on this yearly dataset for the total damaged area and the number of geese assuming all damage 272 could be attributed to cultivated grassland at a yield of 10 tonnes hectare ${ }^{-1}$ year ${ }^{-1}$ (Zwaenepoel 273 2000). This type of grassland is the most prevalent in Flanders (Demolder et al. 2014; Wils et al. 274 2006). The total area of crop loss by $B c$ was then estimated applying the resulting model to the 275 estimated $B C$ population for Flanders. We valued yield loss using a 2014 sales price of hay of $2760.12 € / \mathrm{kg}$ as published by the Belgian Federal Public Service Economy (2015). This price 277 represents an average sales price the farmer can get and is based on Eurostat (2008). We use this 278 price, which does not include subsidies or taxes, as a proxy, as true market prices are unlikely to 279 reflect the true social value of a resource.

280

\section{Calculation of management cost for moult capture}

282

283 Management costs for moult capture were based on data provided by RATO vzw, the principal 284 organisation undertaking moult captures of $B c$ in Flanders. We calculated representative costs for 285 a capture of flock sizes ranging between [30, 105] geese (small capture) and between ]105, 250] 286 geese (large capture) including the costs of preparation (prospecting, planning, requests for 287 permission and permits), transport, personnel and materials used. A small capture involved a cost 288 of $€ 1,004$, a large capture $€ 1,253$ (Table 1). Note there is no big difference in cost between the 
289 two capture sizes. Therefore, we assumed the costs of maintaining a constant capture rate were 290 constant over a range of population densities and thus do not vary within the two capture sizes.

291 Geese naturally flock together on a limited number of suitable moulting sites that are well known

292 to the manager and every capture requires a minimum number of staff. The difference in costs is

293 mainly due to an increase handling time for larger captures and the use of extra vehicles which

294 results in higher transportation costs. Consequently, the average costs per goose were lower as

295 the number of captured geese increased.

296 As the costs for moult capture mainly depend on the number of captures and not on the number

297 of geese, we estimated the number of captures needed to reduce the $B c$ population by $50 \%$ per

298 year applying three steps. First, we calculated the total number of geese captured per year based

299 on the $50 \%$ capture rate. Second, based on real data of capture events from Flanders in the period 300 2010-2014, we estimated the percentage of the total number of $B c$ captured in either a large or

301 small capture event (Table 1). Third, we calculated the average number of $B c$ captured for each

302 of the two categories based on the same data. We then applied these percentages to the total 303 captured population per year todistribute the yearly number of geese captured over the two 304 capture types (large or small). Dividing this number by the average number of geese captured 305 per capture type in the period 2010-2014 determines the number of captures needed. To calculate 306 the moult capture cost, we multiplied this number of captures by the cost per capture. Finally, we

307 calculated total management cost (2014 prices) by multiplying the number of captures for each 308 capture size with the corresponding cost per capture for that capture size.

\section{Population model}

311

312 Under both scenarios (BAU and enhanced scenario) we assumed the growth of the $B c$ population 313 could be described by a logistic growth model (Trost and Malecki 1985) as shown in (1) where $K$

314 is the carrying capacity, $A$ equals $\frac{K-P(0)}{P(0)}, t$ is the time, $P(0)$ the initial population at $t=0$ and $r$ the 315 intrinsic growth rate (Tsoularis and Wallace, 2002).

316

$$
P(t)=\frac{K}{1+A e^{-r t}}
$$


318 The annual population size of $B c$ was taken from the Flemish waterbird census for the period

319 1992-2014 (Devos and Onkelinx 2013; Data S2). Because geese have been systematically

320 captured since 2010 (Figure 1) our population parameter estimates would be biased if we

321 included the post-2009 years in the analysis. We therefore limited the dataset to the period 1992-

322 2009. Non-linear least squares regression (NLS) (Montgomery, Peck \& Vining 2012) was

323 applied to fit the model to the data. Using multiple starting values for $r$ and $K$ we tested if the

324 algorithm converged to the same parameters in each estimation. We defined ranges of [0.25-3]

325 and [5.000,30.000] for $r$ and $K$ respectively and uniformly divided these into 10 pairs of $r$ and $K$

326 starting values. We then re-estimated the model for each pair of starting values (Table 2).

327

328 Capture rate

329

330 The capture rate was defined as the ratio of captured geese divided by the sum of captured and

331 counted geese after the moult capture season. To assess this capture rate, we used data from Van

332 Daele et al. (2012) for Flanders. Estimates based on these data range from 41\% - 56\%. A 50\%

333 capture rate in the enhanced scenario therefore seemed a reasonable value. We further supposed

334 a reduction in geese numbers by moult captures would not affect the parameters of our

335 population model and assumed immigration and emigration to be zero. As the population

336 reproduces before moult capturing, we model the population growth realized after the previous

337 moult capture in a given year (post-moult capture population) and before the next moult capture

338 one year ahead (pre-moult capture population). As we assume a constant capture rate, the post-

339 moult capture population is known. Thus, we can compute equation (2) (the inverse of equation

340 1) yielding a value for time $t$ which corresponds to the same population level the post-moult

341 capture population (Figure 3). This way, we can compute the Bc population one year ahead.

342

$$
t=-\frac{1}{r} \ln \left(\frac{K-P(t)}{A P(t)}\right)
$$

343

344

Present value and sensitivity analysis

345 
346 We combined all data in a bio-economic model to simulate management and damage costs for

347 the BAU-scenario and the enhanced scenario. We used the PV to compare the two scenarios.

348

$$
P V=\sum_{t} \frac{M_{t}+D_{t}}{(1+i)^{t}}
$$

349

350 The formula for the PV is shown in (3) where $M_{t}$ is the management cost at time $t, D_{t}$ damage

351 cost at time $t$ and $i$ is the real discount rate. We thus calculate the total discounted costs under the

352 two scenarios. Discounting costs and benefits is common practice in CBA (Bourdôt et al. 2015;

353 Daigneault and Brown 2013; Pearce, Atkinson \& Mourato 2006). The yearly discount rate was

354 set at $4 \%$ based on guidelines for valuing ecosystem services (Liekens et al. 2013). We

355 discounted management and damage costs to the year 2015 using constant prices of the year

356 2014. To update unit costs for eutrophication to the 2014 price level, we followed Liekens et al.

357 (2013) applying the historical yearly average consumer price index (CPI) with the base year

3582004 (National Bank of Belgium). Management costs and damage costs for lost harvest were

359 already expressed in the 2014 price level.

360

361 Sensitivity analysis was carried out by varying the values for the observed capture rate (41\% and

$36256 \%$ ) and the discount rate, to assess the change of the PV. We varied the capture rate by $10 \%$

363 decrease and increase respectively. These simulations represent a situation with a slower (capture

364 rate - low scenario) and faster (capture rate - high scenario) reduction of the population by moult

365 capture than the observed values respectively. Second, we varied the real discount rate from the

366 initial $4 \%$ to $2.5 \%$ as suggested by Liekens et al. (2013) and Perman et al. (2003). Third, two

367 scenarios were calculated in which we increased the population parameters $r$ and $K$ by $10 \%$. We

368 changed either $r$ or $K$ but not both at the same time. Finally we reduced the sales price of hay by

$36990 \%$.

370 Results

371

372

Population model

373 
374 The estimates for $r$ and $K$ in the population model using the different starting values converged

375 to the same values in all regressions, indicating the robustness of the estimates (Table 2, Figure

376 4). Both parameter estimates for $r$ and $K$ were significant at $\mathrm{p}<0.01$ in all regressions. The 377 estimate for the carrying capacity (10,753 birds) was consistent with Van Daele et. al (2012) who

378 indicated geese numbers stabilized at a population of 10,000-12,000 birds. In our model, the 379 population reached this level in 2010.

380

381 Present value

382

383 The bio-economic model output showed PV was about 9 times lower under the enhanced 384 scenario compared to the BAU scenario. The pooled linear regression model for the estimation 385 of agricultural damage fitted the data well with the number of geese accounting for $55 \%$ of the 386 variation in the damaged area (Figure 5). As such, the agricultural losses avoided in the period 387 2016-2050 under the enhanced scenario amount to an estimated 21,700 $\mathrm{k} €$. For eutrophication, 388 the avoided damage ranged from 2,920-14,850 $\mathrm{k} €$ depending on the unit costs for eutrophication 389 applied. Depending on the unit costs for eutrophication, we found a difference in PV for the 390 BAU and enhanced scenario of 24,370 $\mathrm{k} €$ and 36,300 $\mathrm{k} €$ (Table 3).

391

392 Sensitivity analysis

393

394 Applying different values for the capture rate or the discount rate in the model did not influence 395 the general outcome. At a lower than observed capture rate of $36.9 \%$ (10\% lower as the lower 396 bound of $41 \%$ of the observed rates) as opposed to a $50 \%$ capture rate, $B c$ could not be 397 eradicated within the time horizon 2016-2050. Management costs increased with $120 \mathrm{k} €$ in that 398 scenario when compared with the base scenario of the enhanced scenario (Table 3). The PV 399 under this scenario was still 4 times lower than the BAU scenario, indicating performing 400 additional moult captures was still preferable over BAU. Increasing the capture rate to $61.6 \%$ 401 (10\% higher as the upper bound of $56 \%$ of the observed rates) decreased management costs by $40230 \mathrm{k} €$ when compared to the base scenario of the enhanced scenario. Here, the population 403 reduced faster resulting in a smaller number of captures required. Model output showed that with 404 the higher capture rate the PV was about 14 times lower under the enhanced scenario compared 
405 to the BAU scenario. Under the BAU scenario yearly damage costs rapidly become constant 406 since geese numbers stabilized. Under the enhanced scenario damage costs declined over time. If 407 the discount rate dropped from $4 \%$ to $2.5 \%$, the difference between BAU and moult capture 408 scenario increases due to a higher discount factor $\left(1 /(1+i)^{t}\right)$. Note that in this scenario the BAU 409 costs also change since management and damage costs in both scenarios are similarly discounted 410 with the same discount rate. In the enhanced scenario the ratio of the PV increased to 11 as 411 opposed to 9 in the base scenario. With population parameters $r$ and $K$ increased by $10 \%$ the 412 enhanced scenario is preferred over the BAU-scenario. Even in case of a drastic reduction of $41390 \%$ in the sales price of hay the total damage costs were still higher than the management costs 414 at the lowest unit prices for $\mathrm{N}$ and $\mathrm{P}$ (Table S1). Clearly, the management costs in general are 415 low in all enhanced scenarios.

\section{Discussion}

417

418 The EU-regulation 1143/2014 on the prevention of spread and introductions of IAS requires 419 Member States to conduct cost-benefit analysis in order to identify cost effective control 420 measures to minimize and mitigate IAS impacts. However, performing CBA is often not 421 straightforward since it requires a lot of data on all costs and benefits as well as clear guidelines 422 to decide on underlying assumptions. The relative complexity of CBA in comparison to other 423 methods (e.g. effectiveness analysis, multi criteria analysis) renders the method less useful in 424 support of derogations on the rapid response obligation. However, CBA is especially useful for 425 decision making on the management options for established IAS as it allows assessment of the 426 real management and damage costs under different management scenarios, including the zero 427 management option.

428

429 Cost-benefit analysis for $B c$ in Flanders shows that complementing the current management 430 actions with coordinated moult captures significantly reduces damage costs associated with 431 eutrophication and agricultural losses. Our approach almost certainly underestimated the costs of 432 damage. Although we considered two major impacts (eutrophication and damage to cultivated 433 grasslands), these only represent two of the six impact types identified. In practice, the included 434 costs and benefits in a CBA are often limited to those that are measurable (Weatherly et al. 435 2009). In a conceptual analysis phase, we identified at least six types of impact by $B c$ : 
436 eutrophication of water bodies, damage to agricultural crops, birdstrikes, damage to public health 437 and amenities, damage to biodiversity and to recreational areas such as golf courses. Several of 438 those impacts were not taken into account in the model for various reasons. First, for some 439 impacts assessing their magnitude is complex. For example, $B c$ can have an impact on 440 biodiversity by competing with other bird species (Kumschick and Nentwig 2010; Rehfisch, 441 Allan \& Austin 2010) although this is seldom quantified and has been challenged by other 442 authors (Strubbe, Shwartz \& Chiron 2011). Also, $B c$ is known as an opportunistic species, which 443 breeds early in season and can easily colonize new nesting sites at the expense of other 444 waterfowl (Titchenell and Lynch 2010). Canada geese can destroy conservation value habitat by 445 trampling, leaving impoverished habitat to other wildlife but this effect is often context 446 dependent and difficult to assess (French and Parkhurst 2009). Modelling interactions between $447 B C$ and other species is also complex and difficult to value.

449 Second, although some impacts are quantifiable, data were lacking on the magnitude and extent 450 to which they occur in the study area. For instance, aviation safety is a federal matter so 451 information on the number of birdstrikes only exist for Belgium as a whole and not at the 452 regional level of the study area. $B c$ are recognised as a high risk species for birdstrike, where 453 their large body size and flocking behaviour increase the risk of multiple damaging strikes 454 (Maragakis 2009). In addition to the infrequent costs of catastrophic damage, birdstrikes bring 455 significant costs through increased repairs and delays. This cost was not taken into account in 456 this study but is significant in other countries (Allan 2002). However, some of the effects we did 457 not take into account are expected to be rather small. The effect of geese on golf courses was 458 discarded after a rough calculation of the damage costs. Considering the number of clubs on the 459 web page of the Flemish Golf Association (54 clubs) and crude data on the estimated damage 460 cost per club of which $20 \%$ can be attributed to $B c$ (Williams et al. 2010), we derived a total 461 damage cost of $60 \mathrm{k} €$. However, this calculation was not based on actual geese numbers on golf 462 courses and we therefore did not include it in the analysis. We also expect the damage to public 463 health through direct contact of humans with $B c$ to be insignificant. Although $B c$ are susceptible 464 to highly pathogenic avian influenza (Pasick et al. 2007), transmission of disease or parasites 465 from geese to humans has not been well documented, and human health impact would rather 466 occur indirectly through contact (swimming) with contaminated water or goose droppings 
467 (Converse et al. 1999; Fallacara et al. 2001). Therefore, the choice to consider eutrophication and 468 loss to agricultural crops was a pragmatic approach based on available data. We assumed these 469 two impacts represent the highest share in total damage incurred by $B c$.

470

471 Also, within the agricultural damage considered, we only included part of the potential economic 472 cost i.e. damage to cultivated grasslands. Although we know from empirical data this represents 473 the predominant proportion of crop damage, other type of crops (e.g. winter wheat) are also 474 affected (Van Gils et al. 2009). Estimating the total damage on all crops requires detailed 475 understanding of the foraging behaviour of $B c$, their distribution and abundance in relation to the 476 different crop types. Additionally, a register of damage to crops including affected area and/or 477 compensations paid to farmers would be needed. Currently, these data do not exist for $B c$ in 478 Flanders. $B c$ is a game species and only damage of $B c$ originating from nature reserves are 479 eligible for damage compensation by the government. Moreover, the minimum damage cost has 480 to be $€ 300$, of which $250 €$ is considered to be the risk to be covered by the farmer himself, and 481 farmers have to show they applied preventive measures and have to report damage in a timely 482 manner. Alternatively, data could be collected at a sample of farms through detailed monitoring 483 of geese numbers and the area damaged. Using productivity estimates of agricultural land, the 484 value of the total crop loss could then be calculated using average sales prices (Eurostat 2008). 485 Extrapolation could then be used to assess the total damage for the study region. Since data were 486 lacking we based our estimates on data for another species, greylag goose, applying a correction 487 factor for the higher energy intake by $B c$. Although $B c$ and greylag goose have comparable 488 feeding ecologies and predominantly feed on grasslands, collecting real data on the extent of 489 damage by $B c$ is recommended for two reasons. First, the data could validate the current 490 approach. Second, the real data for $B c$ collected could directly be applied in a damage 491 assessment if enough observations were available for a robust estimation. We believe the results 492 of our CBA are robust since extending the scope of the damage costs would render the enhanced 493 scenario even more preferable.

495 Our CBA approach considered management cost and damage costs but did not consider other 496 type of values associated with $B c$ e.g. ornamental value, value as a game species, meat 497 production, ecosystem services associated with the species. Existence values or recreational 
498 values are components of the total economic value but were not estimated in our cost-benefit

499 framework. Although valuation methods to estimate the magnitude of these type of values exist

500 in the field of environmental economics (MacMillan, Hanley \& Daw 2004), they are generally

501 difficult to quantify. Such methods include contingent valuation to estimate willingness to pay to

502 approximate existence values and the travel cost method to assess the recreational value

503 (MacMillan, Hanley \& Daw 2004; Pearce, Atkinson \& Mourato 2006). Other studies have

504 addressed this issue applying benefit transfer (Plummer 2009) or using stated preference

505 techniques (Rajmis, Thiele \& Marggraf 2016). However, benefits incurred in one region are not

506 necessarily transferable to other study areas. We could not find specific studies for Flanders in

507 which existence values or recreational values for $B c$ are provided. If available, such data would

508 render our CBA more realistic.

509

510 Conducting a CBA generally requires a set of assumptions. First, the timeframe for which costs

511 and benefits are calculated has to be determined. According to Pearce, Atkinson \& Mourato

512 (2006) there are no clear-cut rules to choose a reasonable period. Emerton and Howard (2008)

513 argued in favour of a "sufficiently large" timeframe, in order to capture all potential impacts.

514 Here, we chose to project the goose population until 2050. Census data, particularly post-

515 breeding counts of the wintering population, show $B c$ numbers are stabilizing in Flanders,

516 indicating the population is close to carrying capacity (Devos and Onkelinx 2013), a conclusion

517 supported by our analysis. We therefore think the selected time period was large enough for our

518 purpose. Also, at an assumed capture rate of 50\%, our model indicates $B c$ could be eradicated

519 before that date. However, in reality, an assumed capture rate does not consider real world

520 operational problems with which managers are confronted e.g. the increase in searching costs

521 when the species is getting scarcer. Smith et al. (2005) also assumed the same effort was required

522 to reduce a duck population by $50 \%$, regardless of the number of animals involved. The

523 predictions from the Smith et al. (2005) model were close to the observed results of a subsequent

524 eradication (Robertson et al. 2015a). Therefore, an assumed constant capture rate is not an 525 unreasonable simplification.

526 Second, as the population model represents a key component of our bio-economic model, we

527 required another set of assumptions. Population losses through other methods than moult capture, 
528 such as fertility reduction and shooting during the open season for $B c$, were considered to stay

529 proportional to changes in population sizes due to moult captures.

530 Fertility control by egg reduction was thought to have only a minor impact at the population

531 level, unless conducted in a coordinated manner and over long periods of time alongside other

532 lethal control (Klok et al. 2010). In Flanders, the rather small effect of fertility control at the

533 regional scale reflected the spread and limited accessibility of nests. Yet, the method is

534 frequently used on a local scale (municipality ponds, small nature conservation areas,

535 recreational areas), to lower goose numbers during spring and limit local grazing and

536 eutrophication impacts. Reported numbers of $B c$ culled by shooting have shown a proportional

537 increase with $B c$ numbers in Flanders (Adriaens et al. 2012; Scheppers and Casaer 2008).

538 Therefore, in this CBA we consider moult capture as an additional management action that

539 supplements the BAU scenario and assume that the relative contribution of other management

540 measures to population development remain constant under the enhanced scenario. Population

541 modelling has shown culling birds is more effective in reducing bird numbers than egg reduction

542 irrespective of density dependence (Klok et al. 2010). Bc is a game species in Flanders and good

543 numbers are harvested yearly during the open season.

544 Also, with good time series of goose counts, we assumed a logistic growth curve for the 545 population to estimate intrinsic growth rate and carrying capacity. While a matrix population

546 model, considering reproduction and survival at different life stages, might more accurately

547 project population numbers (Caswell 2001; de Kroon et al. 1986), these models require detailed

548 data on population parameters related to survival, growth rates and fertility of different life

549 stages (Klok et al. 2010). Such data are currently not available for the Flemish population.

550 Considering the need for long time series of goose counts to inform the population model and to

551 estimate carrying capacity, the methodology cannot be usefully applied to newly introduced non-

552 native species. For such species, models could rely on species distribution modelling to estimate

553 the carrying capacity (e.g. Strubbe, Matthysen 2009), and data on their intrinsic growth rates.

554 Another parameter often discussed in literature is the discount factor $1 /(1+i)^{t}$. The discount

555 factor has the consequence that future costs and benefits have less weight in the analysis. As with

556 many environmental and biodiversity related investments, benefits (avoided damages) become

557 apparent only after some time while the costs occur earlier in time. Therefore, the benefits could

558 be undervalued and costs overestimated. From a societal perspective with sustainability 
559 becoming increasingly important in economic decision-making, a high discount rate could 560 rapidly make future costs and benefits insignificant thereby impacting future generations (Pearce, 561 Atkinson \& Mourato 2006; Scarborough 2011). For the discount factor, we relied on

562 recommended reference values available in a regional guideline (Liekens et al. 2013). Perman et 563 al. (2003) also note a discount rate varies between 2-5\%, with a recommendation to use a real 564 discount rate of $4 \%$ in CBA.

565 Finally, we also assumed the benefits of management under an enhanced scenario were not offset 566 by potential increases in the abundance of other goose species such as greylag goose $A$. anser or 567 feral goose. As these species exhibit similar habitat and feeding characteristics (Huysentruyt et 568 al. 2010; Lemaire and Wiersma 2011), lowering $B c$ numbers through management could release them from interspecific competition which could offset some of the benefits of $B c$ management e.g. through increased agricultural damage. To include such multi-species effects in modelling requires further detailed monitoring of geese populations in the study area.

572

573 Cost-benefit analysis can inform decisions on different management options. However, it does 574 not reveal the economically optimal path (e.g. the number of animals to remove per year at 575 minimal management cost) to carry out the management plan. Further research could therefore 576 be conducted to find these optimal paths using dynamic programming techniques (Burnett, 577 Kaiser \& Roumasset 2007; Hauser et al. 2007; Leung et al. 2002). Decision variables in the 578 context of IAS are most strongly influenced by the geographic area over which management is 579 undertaken (Robertson et al. 2015b). These dynamic programming models allow the 580 optimisation of an objective function (e.g. the sum of discounted management and damage costs) 581 under various constraints but are harder to solve mathematically (Hauser et al. 2007). These 582 models are more complex when aiming at comparing different management options or 583 combining different management options in a single model because costs and benefits differ by 584 management option. They allow however to economically optimize the management approach.

586 Our results have broader implications for conducting CBA for IAS management approaches. 587 First, performing CBA requires identification of species impacts and the quantification of those 588 using standardized information available. However, although we were able to place a negative 589 value on an individual bird applying costs for eutrophication and agricultural damage, other costs 
590 may not be scalable in the same way (e.g. conservation impacts). Second, management costs do

591 not always relate to the number of individuals of a species. For example, we showed the

592 management costs for moult capturing geese only varied when a certain threshold number of

593 geese are caught. Third, CBA can be very informative for management decisions, but is often

594 complicated, requires impact types that can be quantified in monetary terms, straightforward

595 population models and may require many assumptions. Cost benefit analysis might also be more

596 appropriate for management of established species than for newly introduced species with

597 limited information on population dynamics, costs and benefits. Finally, CBA requires good

598 registration and documentation of the cost of management performed in the field.

599

600 Conclusions

601

602 The aim of this paper was to apply a bio-economic model in a cost-benefit framework to an IAS.

603 We used Canada goose, Branta canadensis L. as a model species as this species is known to 604 exert severe pressures on the environment and the economy in the study region. We compared a

605 business as usual scenario with a management scenario where these were supplemented with 606 additional coordinated geese moult captures. Our analysis shows CBA to be a valuable 607 framework in support of decisions on IAS management as it supplements risk assessments. It 608 provides a technique to integrate both ecological and economic effects in the decision process on 609 managing biological invasions. Our CBA showed that, under the assumptions of the model, the 610 damage that can be prevented applying additional coordinated moult captures outweighs the 611 extra costs involved. Therefore coordinated moult captures should be considered as an additional 612 management tool whenever the management objective is to limit the negative economic impact 613 of $B c$ at a regional scale. Although every CBA approach has its limitations and assumptions to be 614 met, we believe the large discrepancy between the business as usual scenario and enhanced 615 (BAU + coordinated moult capture) scenario indicates a robust conclusion. This study has shown 616 that it is possible to carry out CBA despite limited data availability. However, we recommend 617 using available national or regional guidelines on CBA to ensure comparability.

618

619 Acknowledgments

620 
621 We thank Karel Van Moer (RATO vzw) for providing cost estimates of moult capture projects, 622 time series of goose captures and additional information. The Agency for Nature and Forest and 623 Inagro vzw provided data on their goose captures. We thank Sander Devisscher for data 624 handling. We are grateful to Thierry Onkelinx for providing information on the population 625 estimates of Canada goose based on waterbird census data. We thank Dr. H. Schekkerman 626 (SOVON Vogelonderzoek Nederland) for information and references on agricultural damage by 627 geese in the Netherlands.

628

629

630

631

References

632

Adriaens T, Baert K, Breyne P, Casaer J, Devisscher S, Onkelinx T, Pieters S, Stuyck J (2015).

633 (Rodentia, Sciuridae) population in Flanders (northern Belgium). Biological Invasions 17: 2517-

Successful eradication of a suburban Pallas's squirrel Callosciurus erythraeus (Pallas 1779) 634 2526. DOI:10.1007/s10530-015-0898-z.

635 Adriaens T, San Martin y Gomez G, Bogaert J, Crevecoeur L, Beuckx JP, Maes D (2015).

636 Testing the applicability of regional IUCN Red List criteria on ladybirds (Coleoptera, 637 Coccinellidae) in Flanders (north Belgium): opportunities for conservation. Insect Conservation 638 and Diversity 8:404-417. DOI: 10.1111/icad.12124.

639 Adriaens T, Huysentruyt F, van Daele P, Devos K, Casaer J (2012). Evaluatie bescherming en 640 beheer van ganzenpopulaties. In: Van Gossum P (ed) Inhoudsevaluatie van natuurbeleid in 641 landbouwgebied: case vogelbeheer en erosiebestrijding. INBO.R.2012.50. Instituut voor Natuur642 en Bosonderzoek, Brussel, pp 29-41. Available on 643 https://pureportal.inbo.be/portal/files/4970422/Adriaens_etal_2012_NARAganzen.pdf

644 Adriaens T, Huysentruyt F, Devisscher S, Devos K, Casaer J (2014). Integrated management of 645 invasive Canada geese populations in an international context: a case study. Neobiota 2014, 8th 646 International Conference on Biological Invasions "Biological Invasions: From understanding to 647 action". Antalya, Turkey.

648 Allan JR (2002). The costs of bird strikes and bird strike prevention. In: Clark L, Hone J, Shivik 649 JA, Watkins RA, Vercauteren KC, Yoder JK (eds) Human conflicts with wildlife: economic 650 considerations. Proceedings of the Third NWRC Special Symposium. National Wildlife 651 Research Center, Fort Collins, Colorado, USA. 
652 Allan JR, Kirby JS, Feare CJ (1995). The biology of Canada geese Branta canadensis in relation 653 to the management of feral populations. Wildlife Biology 1:129-143.

654 Ayers CR, DePerno CS, Moorman CE, Yelverton FH (2010). Canada goose weed dispersal and 655 nutrient loading in turfgrass systems. Applied Turfgrass Science 7:1-6.

656 Bellard C, Cassey P, Blackburn TM (2016). Alien species as a driver of recent extinctions. 657 Biology Letters 12: 20150623. DOI: 10.1098/rsbl.2015.0623.

658 Booy O, Mill AC, Roy HE, Hiley A, Moore N, Robertson P, Baker S, Brazier M, Bue M, 659 Bullock R, Campbell S, Eyre D, Foster J, Hatton-Ellis M, Long J, Macadam C, Morrison-Bell C, 660 Mumford J, Newman J, Parrott D, Payne R, Renals T, Rodgers E, Spencer M, Stebbing P, 661 Sutton-Croft M, Walker KJ, Ward A, Whittaker S, Wyn G (2017). Risk management to prioritise 662 the eradication of new and emerging invasive non-native species. Biological Invasions 19(8): 663 2401-2417. DOI:10.1007/s10530-017-1451-z.

664 Bottrill MC, Joseph LN, Carwardine J, Bode M, Cook C, Game ET, Grantham H, Kark S, Linke 665 S, McDonald-Madden E, Pressey RL, Walker S, Wilson KA, Possingham HP (2008). Is 666 conservation triage just smart decision making? Trends in Ecology \& Evolution 23:649-654. 667 DOI: $10.1016 /$ j.tree.2008.07.007.

668 Bourdôt G, Basse B, Kriticos D, Dodd M (2015). Cost-benefit analysis blueprint for regional 669 weed management: Nassella neesiana (Chilean needle grass) as a case study. New Zealand 670 Journal of Agricultural Research 58:325-338. DOI: 10.1080/00288233.2015.1037460.

671 Burgman MA, Carr L, Godden R, Gregory M, McBride LF, Maguire L (2011). Redefining 672 expertise and improving ecological judgment. Conservation Letters 4:81-87. DOI: 673 10.1111/j.1755-263X.2011.00165.x.

674 Burnett KM, Kaiser BA, Roumasset JA (2007). Invasive species control over space and time: 675 Miconia calvescens on Oahu, Hawaii. Journal of Agricultural and Applied Economics 39:125676 132. DOI: 10.1017/S1074070800028996.

677 Caswell H (2001). Matrix population models. Construction, analysis, and interpretation. 2nd 678 Edn. Sinauer Associates, Inc. Publishers, Sunderland, Massachusetts

679 Conover MR (1992) Ecological approach to managing problems caused problems caused by 680 urban Canada geese. Proceedings of the Fifteenth Vertebrate Pest Conference 1992. Paper 19. 681 http://digitalcommons.unl.edu/vpc15/19 
682 Converse K, Wolcott M, Douchety D, Cole R (1999). Screening for potential human pathogens 683 in fecal material deposited by resident Canada Geese on areas of public utility. USGS National 684 Wildlife Health Center.

685 Cooleman S, Anselin A, Beck O, Kuijken E, Lens L (2005). Verplaatsingen en mortaliteit van 686 Canadese Ganzen Branta canadensis in Vlaanderen. Natuur.oriolus 71:152-160.

687 Daigneault A, Brown P (2013). Invasive species management in the Pacific using survey data 688 and benefit-cost analysis. Landcare Research New Zealand.

689 DAISIE (2009). Handbook of alien species in Europe. Invading Nature - Springer Series in 690 Invasion Ecology. Springer Netherlands.

691 de Kroon H, Plaisier A, van Groenendael J, Caswell H (1986). Elasticity: the relative 692 contribution of demographic parameters to population growth rate. Ecology 67:1427-1431. DOI: $69310.2307 / 1938700$.

694 De Nocker L, Broekx S, Liekens I (2011). Economische waardering van verbetering ecologische 695 toestand oppervlaktewater op basis van onderzoeksresultaten uit Aquamoney, report 696 2011/RMA/R/248. VITO, Mol.

697 De Wit M, Crookes D, Van Wilgen B (2001). Conflicts of interest in environmental 698 management: estimating the costs and benefits of a tree invasion. Biological Invasions 3:167699 178. DOI: $10.1023 / \mathrm{A}: 1014563702261$.

700 Demolder H, Schneiders A, Spanhove T, Maes D, Van Landuyt W, Adriaens T (2014). 701 Hoofdstuk 4 - Toestand biodiversiteit. INBO.R.2014.6194611. In: Stevens M (ed) Natuurrapport 702 - Toestand en trend van ecosystemen en ecosysteemdiensten in Vlaanderen. Technisch rapport 703 INBO.M.2014.1988582. Instituut voor Natuur- en Bosonderzoek, Brussel. Available on 704 https://pureportal.inbo.be/portal/files/6898660/Demolder_etal_2014_Hoofdstuk4ToestandBiodiv 705 ersiteit.pdf

706 Devos K, Onkelinx T (2013). Overwinterende watervogels in Vlaanderen. Populatieschattingen 707 en trends (1992 tot 2013). Natuur.Oriolus 79:113-130.

708 Devos K, T'Jollyn F (2016). Watervogels in Vlaanderen tijdens de winter 2015-2016. 709 Vogelnieuws 27:3-17.

710 Drolet D, Locke A, Lewis M, Davidson J (2014). User-friendly and evidence-based tool to 711 evaluate probability of eradication of aquatic non-indigenous species. Journal of Applied 712 Ecology 51:1050-1056. DOI: 10.1111/1365-2664.12263. 
713 Drolet D, Locke A, Lewis MA, Davidson J (2015). Evidence-based tool surpasses expert opinion

714 in predicting probability of eradication of aquatic nonindigenous species. Ecological

715 Applications 25:441-450. DOI: 10.1890/14-0180.1.

716 Emerton L, Howard G (2008). A toolkit for the economic analysis of invasive species. Global

717 Invasive Species Programme, Nairobi.

718 European Union (2014). Regulation (EU) no 1143/2014 of the European parliament and of the

719 Council of 22 October 2014 on the prevention and management of the introduction and spread of

720 invasive alien species. Official Journal of the European Union 4.11.2014, L317:35-55.

721 Eurostat (2008). Handbook for EU Agricultural Price Statistics V 2.0. URL:

722 http://ec.europa.eu/eurostat/ramon/statmanuals/files/Handbook\%20for\%20EU\%20Agricultural\%

723 20Price\%20Statistics\%202008.pdf

724 Evans T, Kumschick S, Blackburn TM (2016). Application of the Environmental Impact

725 Classification for Alien Taxa (EICAT) to a global assessment of alien bird impacts. Diversity

726 and Distributions 22:919-931. DOI: 10.1111/ddi.12464.

727 Fallacara D, Monahan C, Morishita T, Wack RF (2001). Fecal shedding and antimicrobial

728 susceptibility of selected bacterial pathogens and a survey of intestinal parasites in free-living

729 waterfowl. Avian Diseases 45:128-135. DOI: 10.2307/1593019.

730 Federal Public Service Economy (2015). Landbouw - Index van de landbouwprijzen en

731 gemiddelde prijzen (2001 - juni 2015). http://economie.fgov.be/. Accessed 1 September 2015

732 French L, Parkhurst J (2009). Managing wildlife damage: Canada goose (Branta canadensis).

733 Virginia State University.

734 Genovesi P, Carboneras C, Vila M, Walton P (2014). EU adopts innovative legislation on

735 invasive species: a step towards a global response to biological invasions? Biological Invasions

736 17:1307-1311. DOI: 10.1007/s1053.

737 Gosser AL, Conover MR, Mesmer TA (1997). Managing problems caused by urban Canada

738 geese. Berryman Institute Publication 13, Berryman Institute Publication. Utah State University,

739 Logan

740 Hauser C, Runge M, Cooch E, Johnson FA, Harvey WF (2007). Optimal control of Atlantic

741 population Canada geese. Ecological Modelling 201:27-36. DOI:

742 10.1016/j.ecolmodel.2006.07.019. 
743 Huysentruyt F, Casaer J (2010). Het bepalen van mogelijke herkomstgebieden bij 744 landbouwschade door overzomerende ganzen : Een eerste aanzet voor een modelmatige 745 benadering. INBO.R.2010.9. Instituut voor Natuur- en Bosonderzoek, Brussel.

746 Huysentruyt F, Adriaens T, Devisscher S, Casaer J (2013). Evaluation of a large scale 747 management strategy for summering geese in Flanders and Zealand (Belgium/the Netherlands). 748 Poster presentation Wildlife Society 20th Annual Conference, Milwaukee, WI, USA.

749 Kettunen M, Genovesi P, Gollasch S, Pagad S, Starfinger U, ten Brink P, Shine C (2008). 750 Technical support to EU strategy on invasive species (IAS) - assessment of the impacts of IAS in 751 Europe and the EU (Final module report for the European Commission). Institute for European 752 Environmental Policy (IEEP), Brussels.

753 Klok C, Van Turnhout C, Willems F, Voslamber B, Ebbinge B, Schekkerman H (2010). 754 Analysis of population development and effectiveness of management in resident greylag geese 755 Anser anser in the Netherlands. Animal Biology 60:373-393. DOI: 10.1163/157075610X523260.

756 Kumschick S, Nentwig W (2010) Some alien birds have as severe an impact as the most 757 effectual alien mammals in Europe. Biological Conservation 143:2757-2762. DOI: 758 10.1016/j.biocon.2010.07.023.

759 Lemaire AJJ, Wiersma P (2011). Schatting van de huidige en toekomstige gewasschade door 760 Canadese Ganzen in Nederland. SOVON-informatierapport 2011/01. SOVON Vogelonderzoek 761 Nederland, Nijmegen.

762 Leung B, Lodge DM, Finnoff D, Shogren JF, Lewis MA, Lamberti G (2002). An ounce of 763 prevention or a pound of cure: bioeconomic risk analysis of invasive species. Proceedings of the 764 Royal Society of London B: Biological Sciences 269:2407-2413. DOI 10.1098/rspb.2002.2179.

765 Liekens I, Van der Biest K, Staes J, De Nocker L, Aertsens J, Broekx S (2013). Waardering van 766 ecosysteemdiensten, een handleiding. Studie uitgevoerd in opdracht van LNE, afdeling milieu-, 767 natuur- en energiebeleid 2013/RMA/R/46. VITO, Mol.

768 MacMillan D, Hanley N, Daw M (2004). Costs and benefits of wild goose conservation in 769 Scotland. Biological Conservation 119:475-485. DOI: 10.1016/j.biocon.2004.01.008.

770 Maragakis, I. (2009). Bird population trends and their impact on Aviation safety 1999-2008.

771 Executive Directorate-Safety Analysis and Research Department, European Aviation Safety 772 Agency. 
773 McGeoch MA, Genovesi P, Bellingham PJ, Costello MJ, McGrannachan C, Sheppard A (2016).

774 Prioritizing species, pathways, and sites to achieve conservation targets for biological invasion.

775 Biological Invasions 18:299-314. DOI: 10.1007/s10530-015-1013-1.

776 Melman TCP, de Lange HJ, Clerkx APPM (2011). QuickScan effectiviteit van het weren en

777 verjagen van ganzen.Wageningen, Alterra, Alterra-report 2251. URL:

778 http://edepot.wur.nl/189375

779 Montgomery DC, Peck EA, Vining GG (2012). Introduction to linear regression analysis, 5th 780 edn. John Wiley \& Sons, Inc., Hoboken, New Jersey.

781 Olson LJ (2006). The economics of terrestrial invasive species: a review of the literature.

782 Agricultural and Resource Economics Review 35:178-194. DOI: 10.1017/S1068280500010145.

783 Panzacchi M, Cocchi R, Genovesi P, Bertolino S (2007). Population control of coypu Myocastor

784 coypus in Italy compared to eradication in UK: a cost-benefit analysis. Wildlife Biology 13:159-

785 171. DOI: 10.2981/0909-6396(2007)13[159:PCOCMC]2.0.CO;2.

786 Pasick J, Berhane Y, Embury-Hyatt C, Copps J, Kehler H, Handel K, Babiuk S, Hooper-

787 McGrevy K, Li Y, Mai Le Q, Lien Phuong S (2007). Susceptibility of Canada geese (Branta

788 canadensis) to highly pathogenic avian influenza virus (H5N1). Emerging Infectious Diseases

789 13:1821-1827. DOI: 10.3201/eid1312.070502.

790 Pearce D, Atkinson G, Mourato S (2006). Cost-benefit analysis and the environment: recent 791 developments. OECD Publishing, Paris.

792 Pejchar L, Mooney HA (2009). Invasive species, ecosystem services and human well-being.

793 Trends in Ecology \& Evolution 24:497-504. DOI: 10.1016/j.tree.2009.03.016.

794 Perman R, Ma Y, McGilvray J, Common M (2003). Natural resource and environmental 795 economics. 3rd edn. Pearson Education, Harlow.

796 Perrings C, Dehnen-Schmutz K, Touza J, Williamson M (2005). How to manage biological 797 invasions under globalization. Trends in Ecology \& Evolution 20:212-215. DOI: 798 10.1016/j.tree.2005.02.011.

799 Perrings C, Williamson M, Barbier EB, Delfino D, Dalmazzone S, Shogren J, Simmons P, 800 Watkinson A (2002). Biological invasion risks and the public good: an economic perspective.

801 Conservation Ecology 6: 1-7. URL: http://www.consecol.org/vol6/iss1/art1.

802 Plummer ML (2009). Assessing benefit transfer for the valuation of ecosystem services.

803 Frontiers in Ecology and the Environment 7:38-45. DOI: 10.1890/080091. 
804 Poelmans L, Van Rompaey A (2009). Detecting and modelling spatial patterns of urban sprawl 805 in highly fragmented areas: a case study in the Flanders-Brussels region. Landscape and Urban 806 Planning 93:10-19. DOI: 10.1016/j.landurbplan.2009.05.018.

807 Rajmis S, Thiele J, Marggraf RA (2016). Cost-benefit analysis of controlling giant hogweed 808 (Heracleum mantegazzianum) in Germany using a choice experiment approach. NeoBiota 31: 809 19-41. DOI: 10.3897/neobiota.31.8103.

810 Rehfisch MM, Allan JR, Austin GE (2010). The effect on the environment of Great Britain's 811 naturalized Greater Canada Branta canadensis and Egyptian Geese Alopochen aegyptiacus. 812 BOU Proceedings - The Impacts of Non-native Species.

813 Robertson P, Adriaens T, Caizergues A, Cranswick PA, Devos K, Gutiérrez-Expósito C, 814 Henderson I, Hughes B, Mill AC, Smith GC (2015a). Towards the European eradication of the 815 North American ruddy duck. Biological Invasions 17:9-12. DOI: 10.1007/s10530-014-0704-3.

816 Robertson PA, Adriaens T, Lambin X, Mill A, Roy S, Shuttleworth CM, Sutton-Croft M 817 (2015b). The large-scale removal of mammalian invasive alien species in Northern Europe. Pest 818 Management Science 73: 273-279. DOI:10.1002/ps.4224.

819 Roy H, Schonrogge K, Dean H, Peyton J, Branquart E, Vanderhoeven S, Copp G, Stebbing P, 820 Kenis M, Rabitsch W, Essl F, Schindler S, Brunel S, Kettunen M, Mazza L, Nieto A, Kemp J, 821 Genovesi P, Scalera R, Stewart A (2014a). Invasive alien species - framework for the 822 identification of invasive alien species of EU concern ENV.B.2/ETU/2013/0026. European 823 Commission, Brussels. Available on 824 http://ec.europa.eu/environment/nature/invasivealien/docs/Final\%20report_12092014.pdf.

825 Roy HE, Rabitsch W, Scalera R, Stewart A, Gallardo B, Genovesi P, Essl F, Adriaens T, Booy 826 O, Branquart E, Brunel S, Copp GH, Dean H, D’hondt B, Josefsson M, Kenis M, Kettunen M, 827 Linnamagi M, Lucy F, Martinou A, Moore N, Nieto A, Pergl J, Peyton J, Schindler S, Solarz W, 828 Stebbing PD, Trichkova T, Vanderhoeven S, van Valkenburg J, Zenetos A Developing a 829 framework of minimum standards for the risk assessment of alien species. In press Journal of 830 Applied Ecology. DOI: 10.1111/1365-2664.13025.

831 Roy, H E, H Hesketh, B V Purse, J Eilenberg, A Santini, R Scalera, G D Stentiford, T Adriaens, 832 K BacelaSpychalska, D Bass, K M Beckmann, J Bessell, J Bojko, O Booy, A Cardoso, F Essl, Q 833 Groom, C Harrower, R Kleespies, A Martinou, M van Oers, E Peeler, J Pergl, W Rabitsch, A 834 Roques, F Schaffner, S Schindler, B Schmid, K Schönrogge, J Smith, W Solarz, A Stewart, A 
835 Stroo, E Tricarico, K Turvey, A Vannini, M Vilà, S Woodward, A Wynns, and A Dunn (2016).

836 Alien pathogens on the Horizon: opportunities for predicting their threat to wildlife.

837 Conservation Letters 10:477-484. DOI: 10.1111/conl.12297.

838 Scalera R (2010). How much is Europe spending on invasive alien species? Biological Invasions

839 12:173-177. DOI: 10.1007/s10530-009-9440-5.

840 Scalera R, Genovesi P, Essl F, Rabitsch W (2012). The impacts of invasive alien species in

841 Europe. EEA Technical report No 16/2012. European Evironment Agency, Copenhagen.

842 Available on https://www.eea.europa.eu/publications/impacts-of-invasive-alien-species.

843 Scarborough H (2011). Intergenerational equity and the social discount rate. Australian Journal 844 of Agriculture and Resoure Economics 55:145-158. DOI: 10.1111/j.1467-8489.2011.00532.x.

845 Schekkerman H, Klok C, Voslamber B, van Turnhout C, Willems F, Ebbinge BS (2000).

846 Overzomerende grauwe ganzen in het noordelijk Deltagebied; een modelmatige benadering van

847 de aantalontwikkeling bij verschillende beheersscenario's. Alterra-rapport 139/SOVON-

848 onderzoeksrapport 2006/06. Alterra, Wageningen.

849 Scheppers T, Casaer J (2008). Wildbeheereenheden Statistieken - Rapportering en verwerking 850 over de periode 1998 - 2007. INBO.M.2008.9. Instituut voor Natuur- en Bosonderzoek, Brussel.

851 Available on https://www.vlaanderen.be/nl/publicaties/detail/wildbeheereenheden-statistieken-

852 rapportering-en-verwerking-over-de-periode-1998-2007.

853 Schindler S, Staska B, Adam M, Rabitsch W, Essl F (2015). Alien species and public health

854 impacts in Europe: a literature review. NeoBiota 27: 1-23. DOI: 10.3897/neobiota.27.5007.

855 Schou JS, Jensen F (2017). Management of invasive species: Should we prevent introduction or 856 mitigate damages? Department of Food and Resource Economics, University of Copenhagen.

857 IFRO Working Paper No. 2017/06.

858 http://okonomi.foi.dk/workingpapers/WPpdf/WP2017/IFRO_WP_2017_06.pdf

859 Simonsen CE, Madsen J, Tombre IM, Nabe-Nielsen J (2016). Is it worthwhile scaring geese to

860 alleviate damage to crops? An experimental study. Journal of Applied Ecology 43: 916-924.

861 DOI: $10.1111 / 1365-2664.12604$

862 Smith AE, Craven SR, Curtis PD (2000). Managing Canada geese in urban environments. 863 Cornell Cooperative Extension. 
864 Smith VH, Tilman GD, Nekola JC (1999). Eutrophication: impacts of excess nutrient inputs on 865 freshwater, marine, and terrestrial ecosystems. Environmental Pollution 100:179-196. DOI: 866 10.1016/S0269-7491(99)00091-3.

867 Strubbe D, Matthysen E (2009). Predicting the potential distribution of invasive ring-necked 868 parakeets Psittacula krameri in northern Belgium using an ecological niche modelling approach. 869 Biological Invasions 11:497-513. DOI: 10.1007/s10530-008-9266-6.

870 Strubbe D, Shwartz A, Chiron F (2011). Concerns regarding the scientific evidence informing 871 impact risk assessment and management recommendations for invasive birds. Biological 872 Conservation 144:2112-2118. DOI: 10.1016/j.biocon.2011.05.001.

873 Titchenell MA, Lynch WE Jr (2010). Coping with Canada geese: conflict management and 874 damage prevention strategies. Ohio State University. Available on 875 http://ohioline.osu.edu/factsheet/W-3 (accessed 04 February 2014).

876 Tollington S, Turbé A, Rabitsch W, Groombridge JJ, Scalera R, Essl F, Shwartz A (2015). 877 Making the EU legislation on invasive species a conservation success. Conservation Letters 878 10:112-120. DOI: 10.1111/conl.12214.

879 Tombre IM, Eythórsson E, Madsen J (2013). Towards a Solution to the Goose-Agriculture 880 Conflict in North Norway, 1988-2012: The Interplay between Policy, Stakeholder Influence and 881 Goose Population Dynamics. PLoSONE 8(8): e71912. DOI: 10.1371/journal.pone.0071912.

882 Trost RE, Malecki RA (1985). Population trends in Atlantic Flyway Canada geese: implications 883 for management. Wildlife Society Bulletin 13:502-508. URL: 884 http://www.jstor.org/stable/3782678

885 Tsoularis A, Wallace J (2002). Analysis of logistic growth models. Mathematical Biosciences 886 179:21-55. DOI: 10.1016/S0025-5564(02)00096-2.

887 Van Daele P, Adriaens T, Devisscher S, Huysentruyt F, Voslamber B, De Boer V, Devos K, 888 Casaer J (2012). Beheer van Zomerganzen in Vlaanderen en Zeeuws-Vlaanderen - Rapport 889 opgesteld in het kader van het INVEXO INTERREG project. INBO.R.2012.58. Instituut voor 890 Natuur- en Bosonderzoek, Brussel. Available on www.invexo.be

891 van der Jeugd H, Voslamber B, Van Turnhout C, van Turnhout C, Sierdsema H, Feige N, 892 Nienhuis J, Koffijberg K (2006). Overzomerende ganzen in Nederland: grenzen aan de groei? 893 Sovon-onderzoeksrapport 2006/02. Sovon Vogelonderzoek Nederland, Beek-Ubbergen. 
894 Van Gils B, Huysentruyt F, Casaer J, Devos K, De Vliegher A, Carlier L (2009). Project 895 Winterganzen 2008-2009: onderzoek naar objectieve schadebepaling. INBO.R.2009.56. Instituut 896 voor Natur- en Bosonderzoek, Brussel. Available on

897 https://www.vlaanderen.be/nl/publicaties/detail/project-winterganzen-2008-2009-onderzoek-

898 naar-objectieve-schadebepaling.

899 van Ham C, Genovesi P, Scalera R (2013). Invasive alien species: the urban dimension - Case 900 studies on strengthening local action in Europe. IUCN, Brussels.

901 Vanderhoeven S, Branquart E, Casaer J, D’hondt B, Hulme PE, Shwartz A, Strubbe D, Turbé A, 902 Verreycken H, Adriaens T (2017). Beyond protocols: improving the reliability of expert-based 903 risk analysis underpinning invasive species policies. Biological Invasions 19(9): 2507-2517. 904 DOI: 10.1007/s10530-017-1434-0.

905 Vermeersch G, Anselin A, Devos K (2006). Bijzondere broedvogels in Vlaanderen in de

906 periode 1994-2005: populatietrends en recente status van zeldzame, kolonievormende

907 en exotische broedvogels in Vlaanderen. Instituut voor Natuur- en Bosonderzoek,

908 Brussel. 64 pp.

909 Vila M, Basnou C, Pyšek P, Josefsson M, Genovesi P, Gollasch S, Nentwig W, Olenin S,

910 Roques A, Roy D, Hulme PE, DAISIE partners (2010). How well do we understand the impacts

911 of alien species on ecosystem services? A pan-European, cross-taxa assessment. Frontiers in

912 Ecology and the Environment 8:135-144. DOI: 10.1890/080083.

913 Voslamber B (2011). Canadese Ganzen in Groningen: herkomst ruiende vogels. De Grauwe 914 Gors 39: 128-134.

915 Wainger LA, King DM, Mack RN, Price EW, Maslin T (2010). Can the concept of ecosystem 916 services be practically applied to improve natural resource management decisions? Ecological 917 Economics 69:978-987. DOI: 10.1016/j.ecolecon.2009.12.011.

918 Weatherly H, Drummond M, Claxton K, Cookson R, Ferguson B, Godfrey C, Rice N, Sculpher

919 M, Sowden A (2009). Methods for assessing the cost-effectiveness of public health 920 interventions: key challenges and recommendations. Health Policy 93:85-92. DOI: 921 10.1016/j.healthpol.2009.07.012.

922 Williams F, Eschen R, Harris A, Djeddour D, Pratt C, Shaw RS, Varia S, Lamontagne-Godwin J, 923 Thomas SE, Murphy ST (2010). The economic cost of invasive non-native species on Great 924 Britain. CABI Project No. VM10066. CABI Europe, Egham. 
925 Wils C, Paelinckx D, Adams Y, Berten B, Bosch H, De Knijf G, De Saeger S, Demolder H, 926 Duelinckx R, Lust P, Oosterlynck P, Scheldeman K, t’Jollyn F, Van Hove M, Vandebussche V, 927 Vriens L (2006). Biologische Waarderingskaart van het Vlaamse Gewest. Instituut voor Natuur928 en Bosonderzoek, Brussels.

929 Wittenberg R, Cock MJW (2001). Invasive alien species. A toolkit of best prevention and 930 management practices. CAB International, Wallingford, Oxon, UK.

931 Zwaenepoel A (2000). Veldgids Ontwikkeling van botanisch waardevol grasland. Provincie 932 West-Vlaanderen, Brugge. 
Figure 1

Moult capture effort in Flanders (2010-2015)

Moult capture effort (average number of Canada geese captured) in Flanders (northern Belgium) (2010-2015) with the location of the project area (barred) in northwest Europe: B (Belgium), NL (Netherlands), GB (Great Britain), F (France), D (Germany), L (Luxemburg). Black dots represent average capture size, the number of captures is shown in the dot.
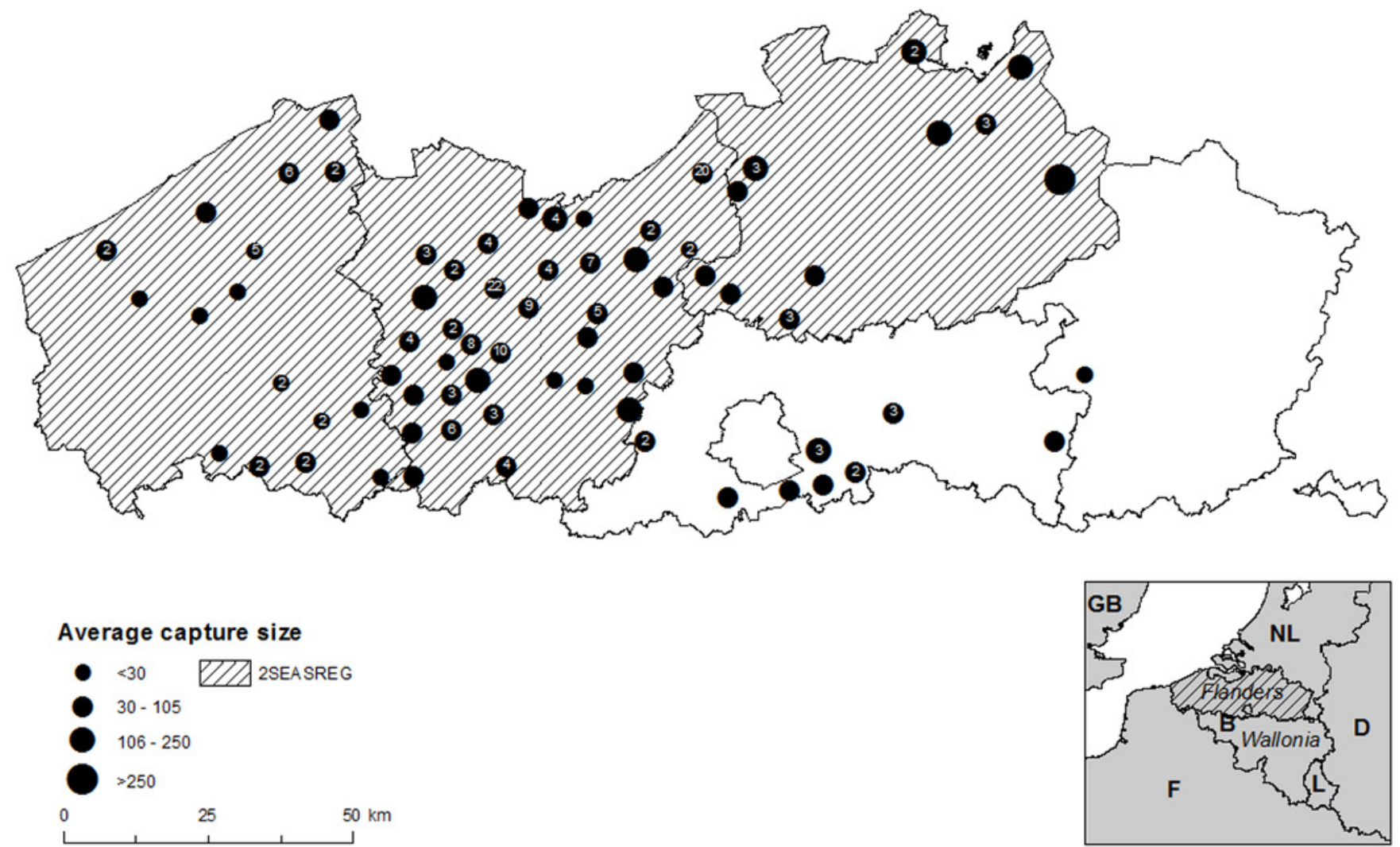
Figure 2

Cost-benefit analysis framework

Schematic representation of the cost-benefit analysis framework for greater Canada goose Branta canadensis L. in Flanders (Northern Belgium).

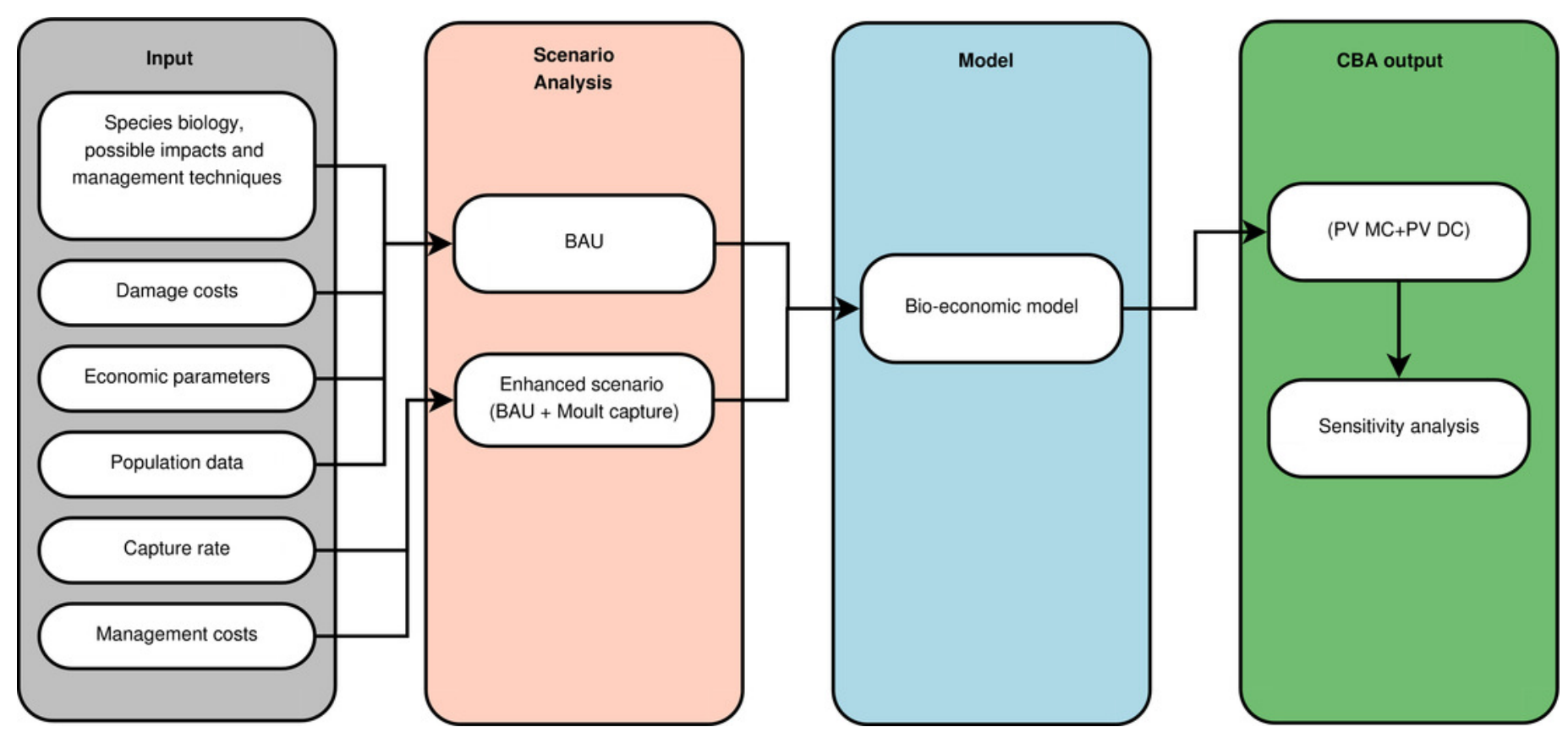




\section{Figure 3}

Schematic representation of the modelled Branta canadensis population growth between two successive moult captures.

$A$ is the pre-moult capture population in a given year, B represents the post-moult capture population in the same year (pushing the population down on the logistic growth curve). $\mathrm{C}$ is the pre-moult population on the next year. The $X$-axis represents a time index. 


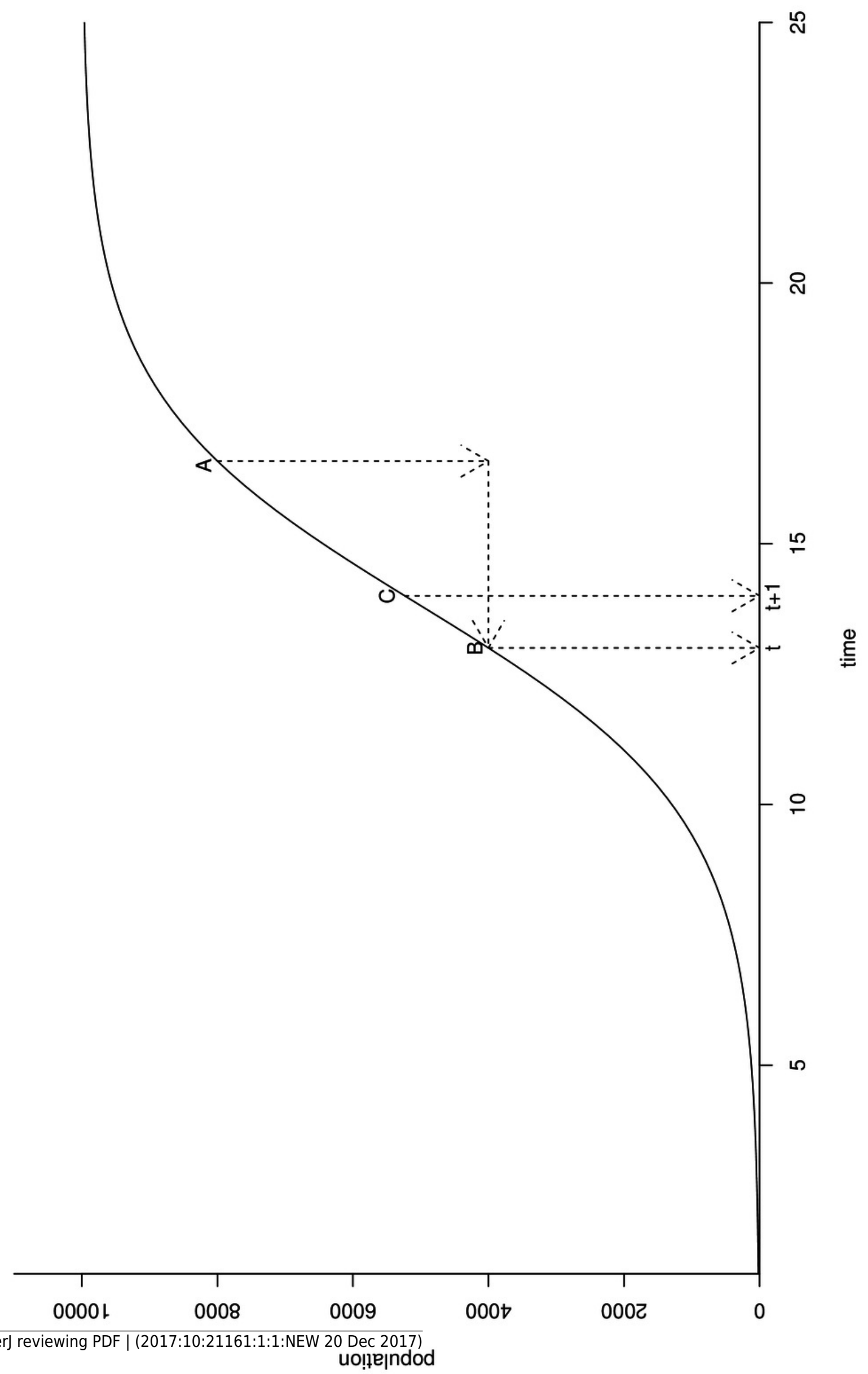




\section{Figure 4}

Logistic growth curve for greater Canada goose in Flanders

Projection (dots) of the greater Canada goose (Branta canadensis) population in Flanders until 2050 under a logistic growth curve. Observed values post 2009 are plotted as triangles. 


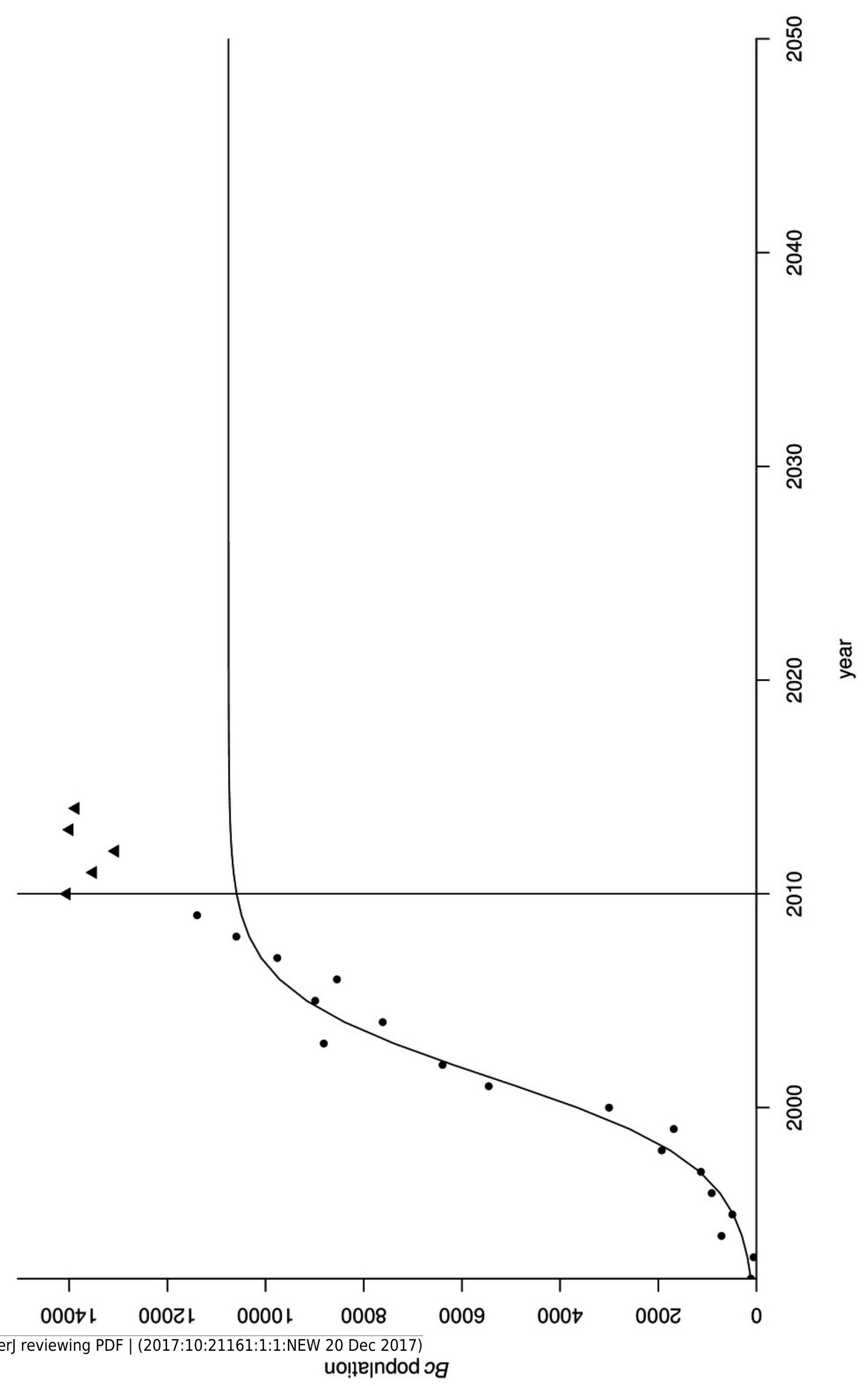


Figure 5

Damage density curve greylag geese

Simple linear regression model of the number of greylag geese Anser anser in the Netherlands versus damaged area. 


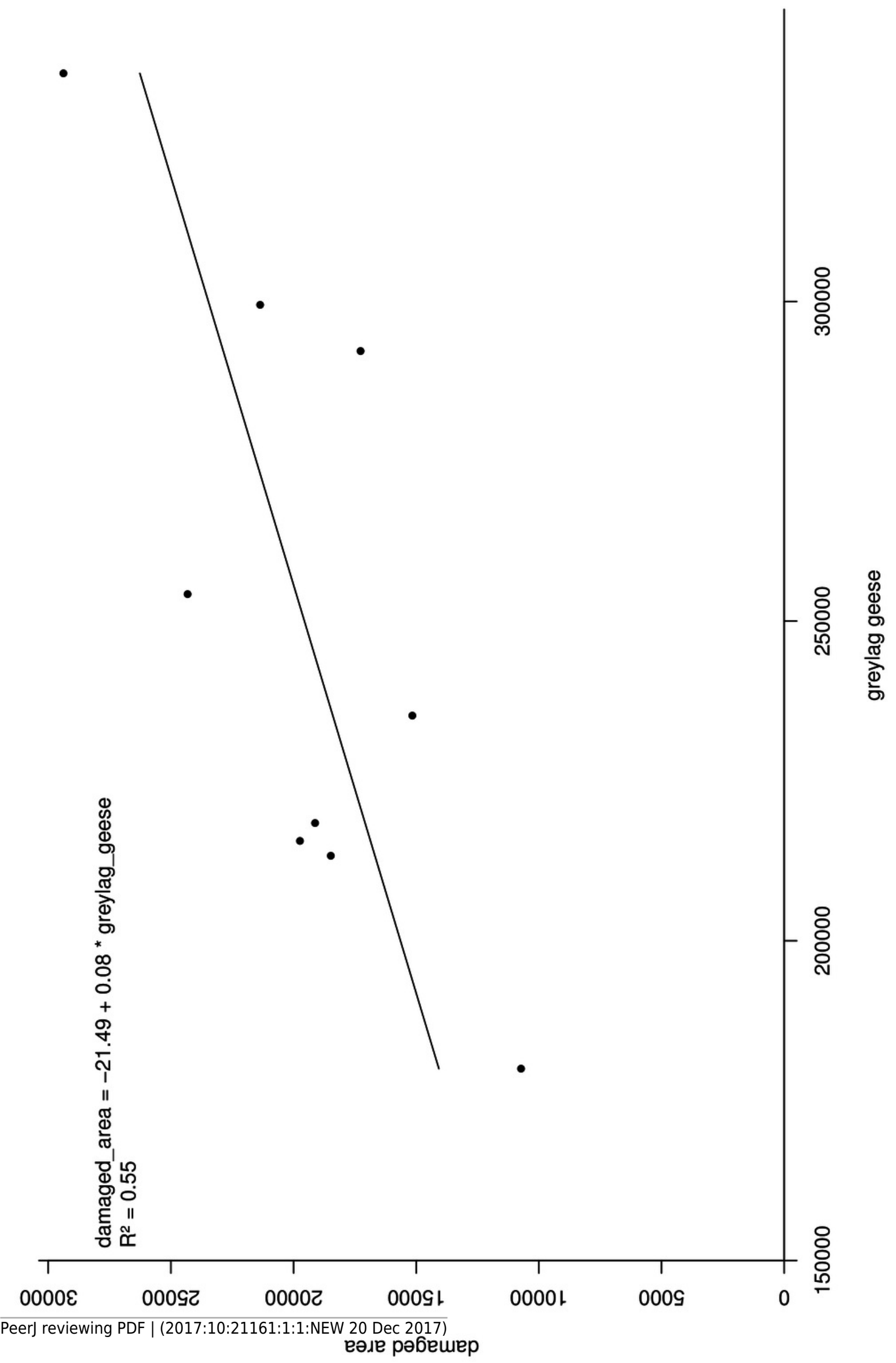




\section{Table $\mathbf{1}$ (on next page)}

Capture size, rate and cost

Percentage and average number of geese captured in small and large capture events and their associated cost based on data from goose captures in Flanders (period 2010-2014). 
Table 1. Percentage and average number of geese captured in small and large capture events and their associated cost based on data from goose captures in Flanders (period 2010-2014).

\begin{tabular}{|c|c|c|c|}
\hline Capture size & $\begin{array}{l}\text { \% of captured } \\
\text { birds }\end{array}$ & $\begin{array}{l}\text { Average number } \\
\text { captured }\end{array}$ & $\begin{array}{l}\text { Calculated representative } \\
\text { cost per capture }(\Theta)\end{array}$ \\
\hline Small $[30,105]$ & $51 \%$ & 46 & $1,004.93$ \\
\hline Large $[105,250]$ & $49 \%$ & 122 & $1,253.15$ \\
\hline
\end{tabular}




\section{Table 2 (on next page)}

Parameter estimates logistic growth curve

Parameter estimates for the logistic growth curve at ten different pairs of starting values for $K$ ( carrying capacity) and $r$ (intrinsic growth rate). 
Table 2. Parameter estimates for the logistic growth curve at 10 different pairs of starting values for $K$ and $r$.

\begin{tabular}{|c|c|c|c|c|c|}
\hline $\begin{array}{c}\text { Startvalue } \\
K\end{array}$ & Startvalue & $\widehat{K}$ & $\hat{r}$ & $\operatorname{se}(K)$ & $s e(r)$ \\
\hline 5000.0000 & 0.2500 & $10753.5900 * * *$ & $0.4838 * * *$ & 408.8097 & 0.0142 \\
\hline 7777.7780 & 0.5556 & $10753.6000 * * *$ & $0.4838 * * *$ & 408.8102 & 0.0142 \\
\hline 10555.5560 & 0.8611 & $10753.6000^{* * *}$ & $0.4838 * * *$ & 408.8100 & 0.0142 \\
\hline 13333.3330 & 1.1667 & $10753.6000^{* * *}$ & $0.4838 * * *$ & 408.8100 & 0.0142 \\
\hline 16111.1110 & 1.4722 & $10753.6000^{* * *}$ & $0.4838 * * *$ & 408.8101 & 0.0142 \\
\hline 18888.8890 & 1.7778 & $10753.6000^{* * *}$ & $0.4838 * * *$ & 408.8101 & 0.0142 \\
\hline 21666.6670 & 2.0833 & $10753.6000 * * *$ & $0.4838 * * *$ & 408.8107 & 0.0142 \\
\hline 24444.4440 & 2.3889 & $10753.5900 * * *$ & $0.4838 * * *$ & 408.8094 & 0.0142 \\
\hline 27222.2220 & 2.6944 & $10753.6000 * * *$ & $0.4838 * * *$ & 408.8100 & 0.0142 \\
\hline 30000.0000 & 3.0000 & $10753.6000^{* * *}$ & $0.4838 * * *$ & 408.8101 & 0.0142 \\
\hline
\end{tabular}

***Significant at $p<0.01, \quad r=$ intrinsic growth rate, $\quad K=$ carrying capacity 


\section{Table 3(on next page)}

Present value calculations

Present value (PV, M€) calculations for the management cost (MC) and damage costs (DC) for the base scenarios (BAU and enhanced scenario) and the low and high capture rate scenarios used in the sensitivity analysis. 
Table 3. Present value (PV, M€) calculations for the management cost (MC) and damage costs (DC) for the base scenarios (BAU and enhanced scenario) and the low and high capture rate scenarios used in the sensitivity analysis.

\begin{tabular}{|c|c|c|c|c|c|c|c|c|c|c|}
\hline \multirow[b]{2}{*}{ TYPE OF COST } & \multicolumn{3}{|c|}{ BASE SCENARIOS } & \multicolumn{2}{|c|}{$\begin{array}{c}\text { CAPTURE RATE } \\
\text { LOW } \\
\end{array}$} & \multicolumn{2}{|c|}{$\begin{array}{c}\text { CAPTURE RATE } \\
\text { HIGH } \\
\end{array}$} & \multicolumn{3}{|c|}{$\begin{array}{c}\text { DISCOUNT } \\
\text { RATE }=2.5 \%\end{array}$} \\
\hline & $\mathbf{B A U}$ & $\begin{array}{c}\text { Enhance } \\
\text { d }\end{array}$ & $\Delta \mathbf{P V}$ & Enhanced & $\Delta \mathbf{P V}$ & Enhanced & $\Delta \mathrm{PV}$ & $\mathbf{B A U}$ & Enhanced & $\Delta \mathbf{P V}$ \\
\hline \multicolumn{11}{|l|}{ PV Damage Costs (DC) } \\
\hline Agriculture & 24.05 & 2.35 & 21.70 & 5.09 & 18.97 & 1.50 & 22.55 & 29.83 & 2.47 & 27.36 \\
\hline \multicolumn{11}{|l|}{ Eutrophication } \\
\hline Unit cost of $\mathrm{N}$ and $\mathrm{P}(\mathrm{low})^{*}$ & 3.24 & 0.32 & 2.92 & 0.69 & 2.55 & 0.20 & 3.04 & 4.02 & 0.33 & 3.68 \\
\hline $\begin{array}{l}\text { Unit cost of } \mathrm{N} \text { and } \mathrm{P} \text { (high, } \\
\text { low)* }\end{array}$ & 16.46 & 1.61 & 14.85 & 3.48 & 12.98 & 1.03 & 15.43 & 20.41 & 1.69 & 18.72 \\
\hline PV Management Costs (MC) & 0.00 & 0.25 & -0.25 & 0.37 & -0.37 & 0.22 & -0.22 & 0.00 & 0.27 & -0.27 \\
\hline \multicolumn{11}{|l|}{ PV DC + PV MC } \\
\hline \multicolumn{11}{|l|}{ Eutrophication } \\
\hline Unit cost of $\mathrm{N}$ and $\mathrm{P}$ (low) & 27.29 & 2.93 & 24.37 & 6.14 & 21.15 & 1.92 & 25.37 & 33.85 & 3.07 & 30.78 \\
\hline Unit cost of $\mathrm{N}$ and $\mathrm{P}$ (high) & 40.52 & 4.22 & 36.30 & 8.94 & 31.58 & 2.74 & 37.77 & 50.24 & 4.43 & 45.82 \\
\hline
\end{tabular}

*High - low unit costs (2014 prices) for N: 5.4 - $79.94 / \mathrm{kg}$ and low for P: $86.42 / \mathrm{kg}$ 